\title{
PSYCHE
}

Vol. 83

September-December, 1976

No. 3-4

\section{STRUCTURE AND RELATIONSHIPS OF THE UPPER \\ CARBONIFEROUS INSECT, EUCAENUS OVALIS (PROTORTHOPTERA: EUCAENIDAE)}

\section{By Frank M. Carpenter ${ }^{1}$ and Eugene S. Richardson, JR. ${ }^{2}$}

In 1885 S. H. Scudder described as Eucaenus ovalis a Pennsylvanian (Upper Carboniferous) insect preserved in a concretion from the Francis Creek Shale in northeastern Illinois. Subsequently, a few additional specimens of the same insect were described by Melander (1903) and Handlirsch (1906a, 1911) from the same beds. Unfortunately, none of these specimens were sufficiently well preserved to give a satisfactory concept of the insect. In recent years, however, and for the most part through the activities of local amateur collectors, a surpiisingly large number of specimens of ovalis, many of them well preserved, have been found in spoil heaps of strip mines dug to coal just beneath the shale (see Richardson and Johnson, 1971). As a result, Eucaenus ovalis is now one of the two or three best known Upper Carboniferous insects from anywhere in the world. The present account is based on a study of all the specimens of the species at present available. ${ }^{3}$

For the opportunity of examining new material, previously unstudied, we are grateful to the following individuals, who have collected the specimens and loaned them to us: Mr. Frank A. Greene, Coal City, Illinois; the late Mr. Levi Sherman, formerly of Des Plaines, Illinois; Mr. and Mrs. Francis Wolff, Port Charlotte, Florida; Mr. Lanny Morreau, Normal, Illinois; and

\footnotetext{
'Harvard University, Cambridge, Massachusetts 02138

${ }^{2}$ Field Museum of Natural History, Chicago, Illinois 60605

${ }^{3}$ Partial financial support of this research is gratefully acknowledged to the National Science Foundation: Grants numbered GB 39790 and DEB 76-04861, F. M. Carpenter, Harvard University, Principal Investigator; and GB 5772, Ralph G. Johnson and Eugene S. Richardson, Jr., Field Museum of Natural History, Principal Investigators.
} 
the late Jerry Herdina (formerly of Berwyn, Illinois), whose collection has subsequently been donated to the Field Museum of Natural History.

Examination of previously studied specimens, including types, has been made possible through the courtesy of the curatorial staff of the following institutions: Illinois State Museum, Springfield, Illinois; National Museum of Natural History, Smithsonian Institution, Washington; and the Peabody Museum, Yale University. The extensive series of unstudied specimens and of types in the Field Museum of Natural History has been essential for our investigation.

\section{Order Protorthoptera Handlirsch, $1906^{4}$}

\section{Family Eucaenidae Handlirsch}

Eucaenidae Handlirsch, 1906a, p. 709; 1906b, p. 164; 1919, p. 52; 1920, p. 161. Teneopteridae Richardson, 1956, p. 56

This family embraces a single genus, which in turn is known from but a single species. We suggest that the following characters are significant on the family level. Fore wing coriaceous; costal area wide; SC, Rl and main stem of RS close together, parallel; all major veins arising near base; RS pectinate; CUP strongly concave, aligned in part with the anal furrow; anal area small. Hind wing membranous. Head slender, antennae long, setaceous, most of the segments alike; mandibles dentate; maxillary palpi very long; eyes small but prominent; prothorax long and broad, covered posteriorly with heavily sclerotized pronotum; legs similar; femora stout, tibiae slender, tarsi with 5 tarsomeres; abdomen no longer than thorax plus head; 11 th segment with very short cerci; some or all abdominal segments with posteriorly directed lateral lobes; females with short ovipositor; femora, tibiae, and thoracic tergites prominently sculptured.

Handlirsch's several definitions of this family emphasized what he took to be blattoid characters of its single genus, Eucaenus. Richardson's definition of the family Teneopteridae was based

\footnotetext{
${ }^{4} \mathrm{We}$ are including in this order the species variously assigned by some students of fossil insects to the orders Paraplecoptera and Protoblattodea, as well as those in the order Protorthoptera (s.s.). The reasons for this treatment have been summarized by Carpenter (1966, pp. 51-55).
} 
on what we now recognize to be two abnormally preserved individuals of the same genus. Our reasons for placing these families in synonymy and our understanding of the relationships of the Eucaenidae will be brought out in the following discussion. The family is known at present only from the ironstone concretions of the Francis Creek Shale of Grundy, Will, and Kankakee Counties, Illinois.

\section{Genus Eucaenus Scudder}

Eucaenus Scudder, 1885, p. 325; Handlirsch, 1906a, p. 710; 1906b, p. 165; 1911 , p. 359.

Teneopteron Carpenter, 1943, p. 359; Richardson, 1956, p. 46.

Since only one genus is known in the family and only one species in the genus, generic characteristics can be stated only in general terms, especially in view of the variation in venation within some species of Protorthoptera (see Carpenter, 1966, p. 73). In all probability the extent of branching of $\mathrm{RS}$ and $\mathrm{M}$ will provide the best source of generic differences in the wings and the forms of the prothorax and legs for the body differences.

Type-species: Eucaenus ovalis Scudder.

\section{Eucaenus ovalis Scudder}

Eucaenus ovalis Scudder, 1885, p. 325, pl. 29, fig. 4; Handlirsch, 1906a, p. 710; 1906 b, p. 165 , pl. 16 , figs. 17 , 18; 1911, p. 359 , figs. $36-41 ; 1920$, p. 162 , fig. 112 . Eucaenus mazonus Melander, 1903, p. 188-190, pl. 6, fig. 3, pl. 7, fig. 10; Handlirsch, 1906a, p. 710; 1906b, p. 165, pl. 16, fig. 19; not 1911, p. 32, fig. 32 .

Eucaenus attenuatus Melander, 1903, p. 190, pl. 6, fig. 4, pl. 7, fig. 11; Handlirsch, 1906 a, p. $710 ; 1906$ b, p. 165 , pl. 16, figs. $20,21$.

Eucaenus minor Handlirsch, 1911, p. 361-362, figs. 40, 41.

Teneopteron mirabile Carpenter, 1943, p. 17-20, fig. 5, pl. 5, fig. 4; Richardson, 1956 , p. 45-52, figs. 26-30.

Fore wing (figure 1): length, 19-24 mm.; width, 7-8 mm; oval, with broadly rounded apex, rounded front margin and very slightly rounded hind margin; wing membrane coriaceous, apparently with a faint reticulation of ridges. Costal area broad, broadest at about mid-wing, somewhat narrowed basally; costal veinlets oblique, numerous, probably more than 30 ; SC nearly straight, slightly arched away from the costa, terminating on costa at about $4 / 5$ of wing length; R1 parallel and close to SC, its termination not definitely known, but a few distal branches 


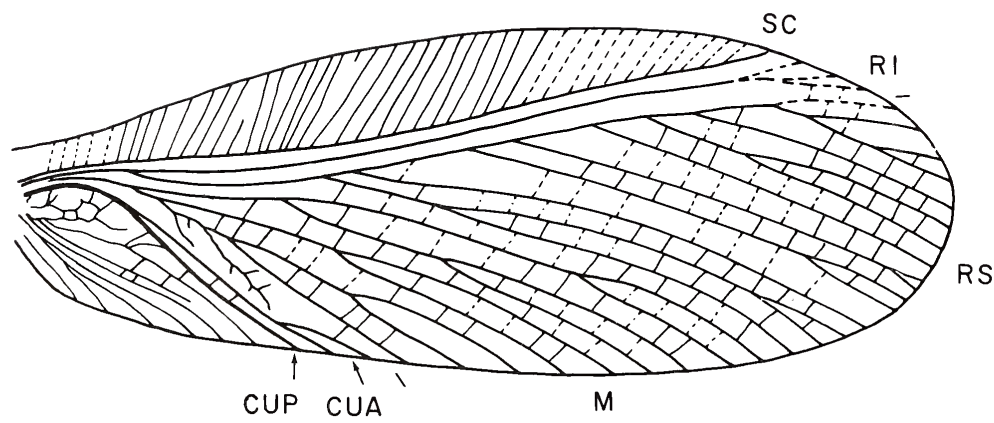

Figure 1. Eucaenus ovalis. Drawing of fore wing, based mainly on the Greene specimen, G75, and the Sherman specimen, W57, with details from other specimens mentioned in the text. The veins indicated by broken lines are not clearly discernible in any specimen. SC, subcosta (-); R1, first radius (+); RS, radial sector (-); M, media ( \pm ); CUA, anterior cubitus (+); CUP, posterior cubitus (-).

are indicated in some specimens; RS with 6-8 (possibly more) pectinately arranged branches, arising at irregular intervals, the first one at about $1 / 3$ of wing length, some of them bifurcating once or twice; $M$ well developed, not so extensive as RS, forking at about the level of origin of RS into two main branches, each with 4 or 5 terminal branches arising by secondary and usually tertiary dichotomous branching; $\mathrm{CU}$ a strong vein basally, dividing below the origin of RS into CUA and CUP, the former weakly convex, with little or no branching, the latter strongly concave; anal veins weak and irregular. Cross veins numerous but weak, not aligned across veins.

Hind wing: only the basal part along the front margin and the apical area are known; costal area narrow, distal part of RS dichotomously branched.

Body structure (figure 2): total body length ranges from 29$32 \mathrm{~mm}$. Head about $3.8 \mathrm{~mm}$ long, maximum width (across eyes) $2.5 \mathrm{~mm}$; mandibles dentate; antennae about $10 \mathrm{~mm}$ long, the first 3 segments a little broader than the others, which are about $0.2 \mathrm{~mm}$ wide and a little more than $0.5 \mathrm{~mm}$ long; total number of segments about 20. Maxillary palpi $7 \mathrm{~mm}$ long, apparently consisting of 4 segments; the basal segment very short (about $.7 \mathrm{~mm}$ ), the $2 \mathrm{nd}$ and $3 \mathrm{rd}$ segments about $2.5 \mathrm{~mm}$ long, and the 
4th, $1.3 \mathrm{~mm}$ long and much thinner than the others. ${ }^{5}$ Head narrowed posteriorly; between the head and the pronotal shield is a demarcated region ( $1.8 \mathrm{~mm}$ wide and $1.5 \mathrm{~mm}$ long), which, because of its heavy sclerotization, we consider to be part of the prothorax, rather than the cervix; pronotal shield elongate-oval, about $5.5 \mathrm{~mm}$ long and $3.8 \mathrm{~mm}$ wide, with the sides only slightly curved and with the maximum width at the posterior half; the pronotal shield is very heavily sclerotized. Mesothorax about $5.5 \mathrm{~mm}$ wide and $4 \mathrm{~mm}$ long; metathorax about $5.4 \mathrm{~mm}$ wide and $3 \mathrm{~mm}$ long. All legs are short and similar in form. The fore femur is $4 \mathrm{~mm}$ long and $2 \mathrm{~mm}$ wide, with a curved front margin; the tibia is $3.8 \mathrm{~mm}$ long, and the tarsus, $1.6 \mathrm{~mm}$ long; four tarsomeres are distinct and there is a suggestion of a fifth. The mesoand metathoracic legs are similar to those of the prothorax. except for slight differences in the lengths of the femora.

The abdomen averages about $14 \mathrm{~mm}$ long, the precise length depending on the amount of contraction of the segments: the width of the first few segments is $5.4 \mathrm{~mm}$ and that of most of the others, $4.5 \mathrm{~mm}$. The cerci are very small, only about $1 \mathrm{~mm}$ long, but they appear to consist of 3 or possibly 4 segments. The female has a short, external ovipositor, $3.4 \mathrm{~mm}$ long, and definitely not extending beyond the end of the abdomen.

The integument of this insect is strongly sclerotized and has a distinctly rugose sculpturing, similar to that of many existing Orthoptera; the sculpturing covers the femora and tibiae, and is especially well developed on the thorax.

Type: no. 38142, National Museum of Natural History, Washington. Scudder saw only the obverse part of this specimen (marked "a"); the reverse part (marked "b"), now in the National Museum, is much better than the one Scudder studied, and we have been able to expose the head and prothorax, which were unknown to Scudder. The total length of the body is $30 \mathrm{~mm}$.

The type of E. mazonus Melander, no. U.C. 9242 in the Walker Museum, University of Chicago [now in Field Museum] shows nothing to distinguish it from ovalis. Melander stated that the

In specimen no. PE 20790 the 4 th segment of the palpus shows faint traces of division into 6 or 8 segments. However, since such palpal segmentation is unknown in the insects, we believe this apparent segmentation in the fossil is associated with the process of preservation. 
diagnostic feature was the shape of the "scapular" vein (R1), which formed an opposing curve to the costa. He was led to conclude from Scudder's drawing that R1 in ovalis was parallel to the costa. However, Scudder's account in this respect was incorrect and the reverse of the ovalis type shows clearly the opposing curvature of the costa and of R1. The total length of the body of the type of mazonus is $29 \mathrm{~mm}$. In this connection, we should note that the Yale University specimen that Handlirsch (1911) identified and figured as mazonus (YPM 51) is not even a eucaenid. The specimen consists of parts of the hind wings and body, the front wings being completely absent. The fore femur, correctly drawn by Handlirsch, is long and slender, unlike that of ovalis. The venation of the hind wing of ovalis, as previously noted, is very little known, but what is known is very different from that of the Yale specimen identified by Handlirsch as mazonus. This represents a small species, incidentally, with a body-length of only $19 \mathrm{~mm}$.

E. attenuatus Melander (1903), in our opinion, is also ovalis. The type specimen, no. 4749 in the Eagan collection of the Chicago Academy of Sciences, has not been found there at this time. However, Melander's description fits ovalis perfectly. He considered the specimen distinct from ovalis because his specimen did not possess the "median keel" on the last abdominal segments, as described by Scudder in his account of the type of ovalis. However, the "keel" is the ovipositor, now known to be characteristic of ovalis females. The type of attenuatus was stated by Melander to have a body length of $28 \mathrm{~mm}$. Handlirsch (1906a) identified a specimen in the National Museum of Natural History (no. 38828) as attenuatus. He obviously never saw the type of attenuatus; his specimen is clearly ovalis, though it appears somewhat smaller than usual because it lacks the head and part of the prothorax. A second specimen (no. 33827) which Handlirsch (1906a) also identified as attenuatus is not even a eucaenid. The venation is not preserved, but there is a long, exserted ovipositor, extending far beyond the end of the abdomen. As noted above, the ovipositor in Eucaenus is very short and does not extend beyond the tip of the abdomen.

Eucaenus minor Handlirsch (1911) was based on a fragmentary specimen (YPM 47) in the Yale University Collection. Handlirsch considered it a separate species or "at least a variety" of 


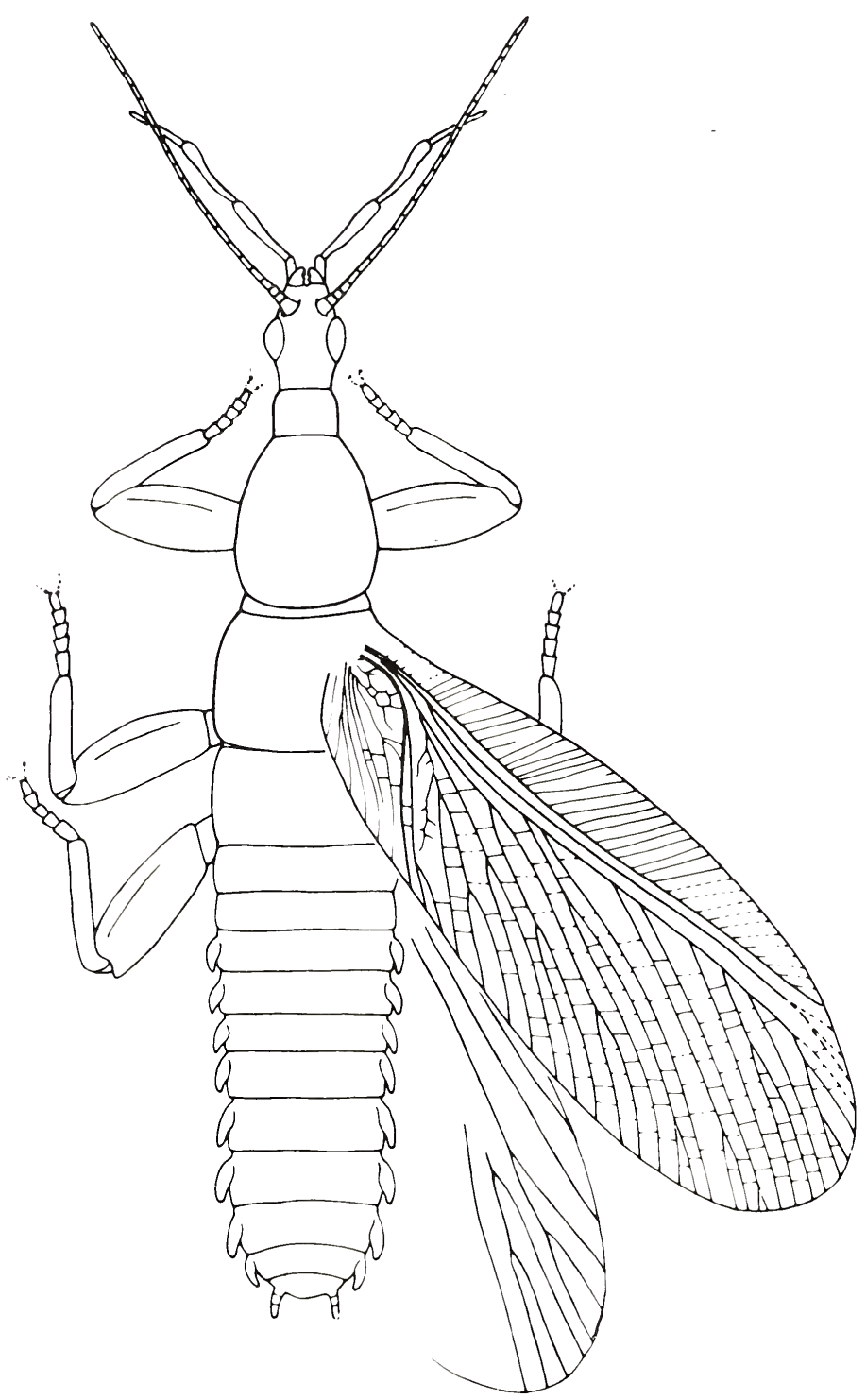

Figure 2. Eucaenus ovalis. Composite drawing based on specimens mentioned in the text. All structures shown are present in at least one specimen, except for those represented by broken lines. See figures 3 and 5 . 
ovalis. Only the basal parts of the wings are preserved and their venation, so far as discernible, is like that of ovalis; the wing length is $22 \mathrm{~mm}$.

Teneopteron mirabile Carpenter (1943) is clearly a synonym of ovalis. In the type specimen (Illinois State Museum, no. 14887) the fore wings were outstretched, but only the costal area and Rl were preserved, so that the wings appeared as elongate elytra. A somewhat similar specimen, now in the Field Museum (PE 967), showing a little more wing surface below R1 than the type but still looking elytrophorous, was described by Richardson in 1956. Enough of the wings and body structure is preserved in these two specimens to show that they are ovalis.

As a final comment on the systematics of the species that have been described in Eucaenus, we should point out that two additional insects placed by Handlirsch in that genus do not in fact belong to the Eucaenidae: E. rotundatus and pusillus. The type of the former, no. 38153, National Museum of Natural History, could not be found there. However, Handlirsch's description (1906a), even as revised by him in 1911, states that RS had only three branches and that CUA was very extensively branched. This is precisely the opposite of the condition in the Eucaenidae. E. pusillus (1911), based on specimen YPM 52 in the Yale collection, is a small insect, about $15 \mathrm{~mm}$ long. We are unable to perceive the venational details shown in the left fore wing of Handlirsch's figure (1911, p. 43) but we do note that the costal area is very narrow; in addition, the fore femur is long and slender, not at all like that of the Eucaenidae. These two species are clearly Protorthoptera but their family positions are certainly obscure and for the present they should be listed as in the Protorthoptera, family and genus indet.

\section{Specimens of Eucaenus ovalis studied}

We have been able to examine twenty-one specimens of ovalis in the course of this investigation. For convenience of reference, we include here an annotated list of these: ${ }^{6}$

\footnotetext{
${ }^{6}$ The following are the localities to which reference is made in the list of specimens. Mazon Creek: the bed of the stream, 4 miles west and a mile north of Coal City. Coal City: strip mines 1 to 2 miles north of Coal City. Pit Eleven: strip mine in Will and Kankakee Counties, 3 to 5 miles south of Braidwood.
} 
1. National Museum, No. 38142. Mazon Creek. Holotype of ovalis. Female; general form of entire insect but with few details preserved; prothorax and head have now been exposed; ovipositor distinct. Fore wing length $22 \mathrm{~mm}$; body length, $30 \mathrm{~mm}$.

2. National Museum, No. 38810. Mazon Creek. Mentioned by Handlirsch (1906a) but not described or figured. Female; shows shape of fore wing clearly, though venation is indistinct; fore and middle femora, cerci, ovipositor and distal part of hind wing well preserved.

3. National Museum, No. 38820. Mazon Creek. Mentioned by Handlirsch (1906a) but not figured or described. Male; entire insect shown but poorly preserved; head and prothorax now exposed; prothoracic shield very clear.

4. National Museum, No. 38828. Mazon Creek. Identified by Handlirsch (1906a) as attenuatus Melander. Male; poorly preserved but with enough wing and body structures for identification.

5. Peabody Museum, No. YPM 47. Mazon Creek. Holotype of E. minor Handlirsch; very poor, fragmented specimen but determination as ovalis virtually certain.

6. Peabody Museum, No. YPM 48. Mazon Creek. Mentioned by Handlirsch (1911). Female; very poor preservation; costal veinlets fewer than usual.

7. Peabody Museum, No. YPM 49. Mazon Creek. Mentioned by Handlirsch (1911). Very poor preservation of entire specimen, with only vague outlines of body and wings.

8. Peabody museum, No. YPM 50. Mazon Creek. Very poor specimen showing entire insect; hind femora and cerci distinct.

9. Illinois State Museum, No. 14887. Coal City. Holotype of Teneopteron mirabile Carpenter. Male; poorly preserved and fragmentary but shows abdomen well, especially the lateral lobes on some of the posterior segments.

10. Field Museum, No. PE 976. Coal City. Described by Richardson as second specimen of $T$. mirabile. Female; poor preservation and fragmentary, but shows hind femora, tip of hind wing, ovipositor and general abdominal segmentation.

11. Frank Greene collection, No. G75. Pit Eleven. Excellent preservation of entire insect except end of abdomen; wings and body particularly good, including head, with antennae, eyes, palpi; prothorax, femora and tibiae clearly preserved. 


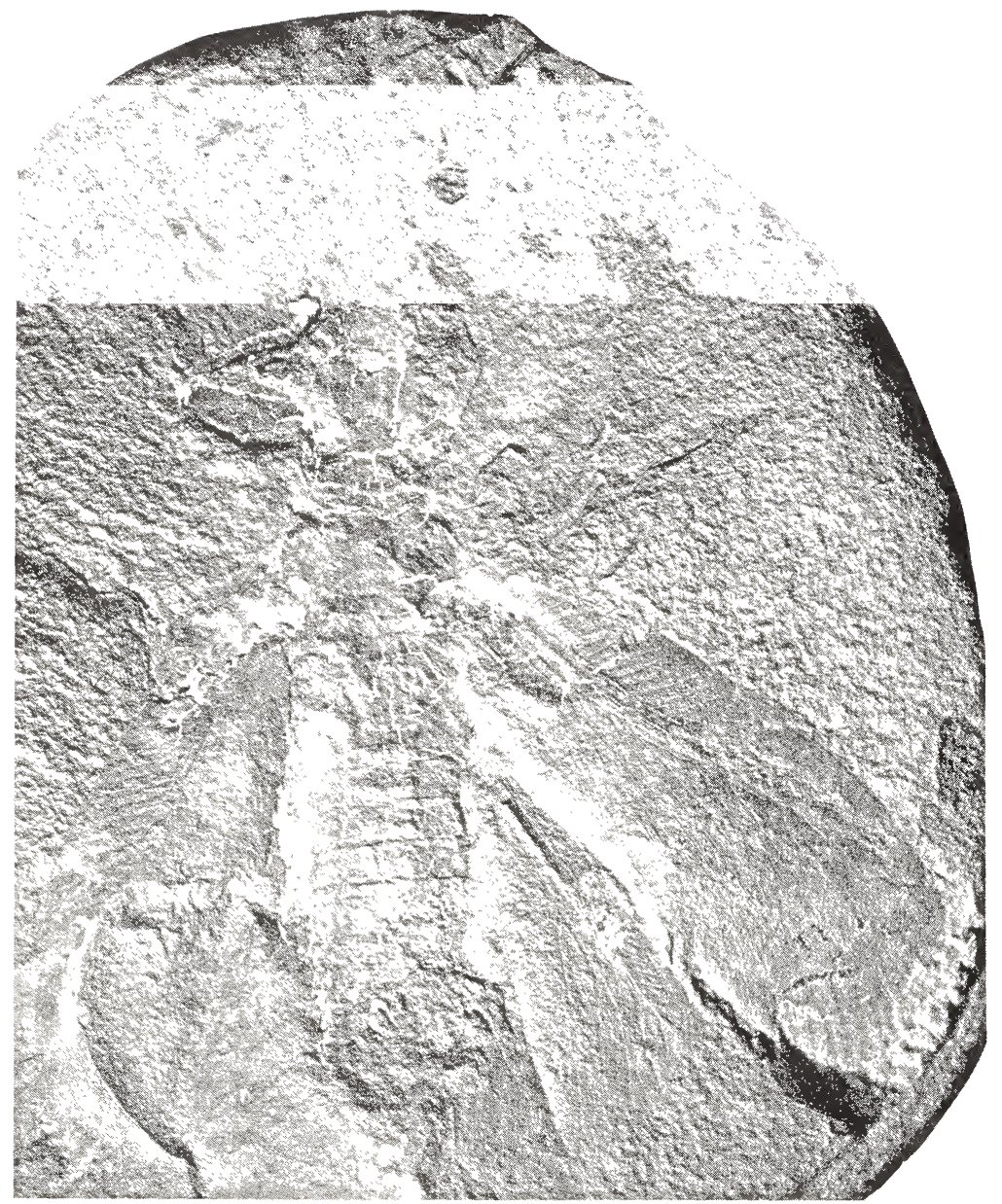

Figure 3. Eucaenus ovalis. Photograph of the Greene specimen, G75 (reverse), under oblique lighting. Note distinct region between head and pronotal shield. Length of fore wing, $20 \mathrm{~mm}$. Compare with figure 4 . 


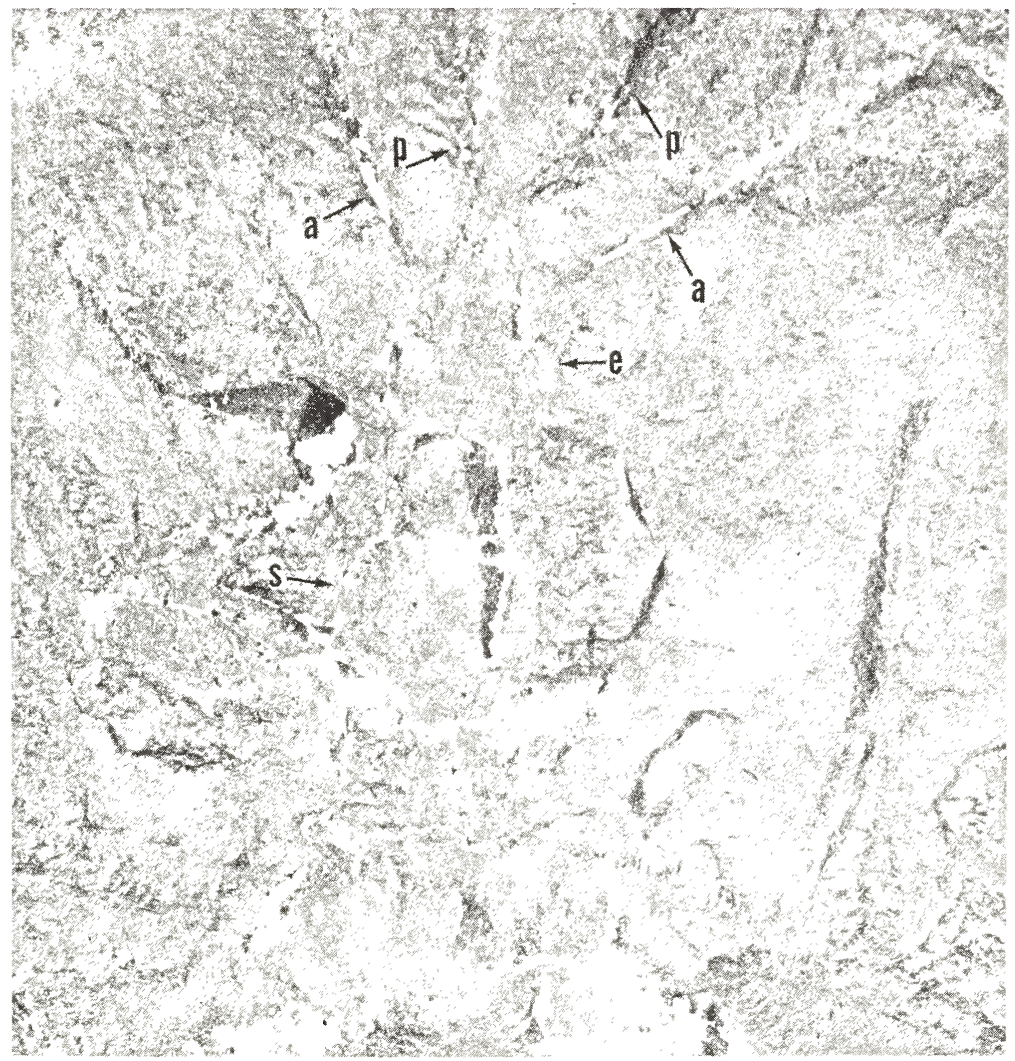

Figure 4. Eucaenus ovalis. Photograph of anterior part of the Greene specimen, G75, under balanced light, without shadows, showing details of head and prothorax. Lettering: e, compound eye; a, antenna; p, palpus; s, pronotal shield. Length of head, $3.8 \mathrm{~mm}$. 
12. Levi Sherman collection, No. W57. Probably Pit Eleven. Female; exceptional preservation of many details; fore wing venation faint, but basal part of wing very clear; also cross veins in distal part of fore wing, base of antennae, mandibles, all femora and ovipositor. Costal area with relatively few veinlets.

13. Wolff collection, No. 243. Preservation poor; abdomen missing but some good details of thorax, expecially prothorax; head in hypognathous position.

14. Wolff collection, No. 653. Female; very incomplete specimen but excellent for anal area of fore wing; hind femora and ovipositor good.

15. Morreau specimen. Pit Eleven. Very poor preservation but determination as ovalis virtually certain.

16. University of Chicago, No. 'U.C. 9242 (at Field Museum). Mazon Creek. Holotype of E. mazonus Melander. Male; preservation poor, but shows femora, tibiae and tarsi.

17. Field Museum, No. PE 20790. Pit Eleven. Entire insect; abdomen not preserved, wings folded back and venation jumbled; head and thorax excellent: head, antennae, palpi, prothorax and legs. Cross veins clear in several areas of fore wings.

18. Field Museum, No. PE 31959 (Herdina 417). Pit Eleven. Male; preservation fair of head, prothorax and wings.

19. Field Museum, No. PE 32038 (Herdina 476). Coal City. Very poor preservation but enough to permit identification.

20. Field Museum, No. PE 32065 (Herdina 212). Pit Eleven. Male; preservation only fair, but prothorax very good.

21. Field Museum, No. PE 32067 (Herdina 213). Pit Eleven. Male; entire insect faintly and poorly preserved; no details of body.

Since no one specimen gives a satisfactory concept of this insect, a composite drawing is included in figure 2 . The general habitus of the insect, as drawn, is based on the Frank Greene specimen, (G75; see photographs, figures 3 and 4), and details have been added from other fossils, as follows, the numbers referring to the specimens in the foregoing list: head (including eyes, maxillary palpi, antennae, mandibles), 11, 12, 17; prothorax, 3, $11,12,13,17$; rest of thorax, 11, 12, 17; fore wings, 2, 11, 12, 14; hind wing (fragments only), 2, 10; legs, 2, 8, 10, 11, 12, 14, 16, 17: abdomen, 2, 9, 10, 11, 12; cerci, 2, 8; ovipositor, 2, 10, 12, 14. All structures shown in the figure are preserved in one or more 
of the fossils studied, with the exception of the few veins shown in broken lines.

\section{Discussion of the Structure of Eucaenus ovalis}

Head. The head of ovalis was presumably opisthognathous and it is so preserved in several specimens; however, it is also shown in a prognathous position in a few fossils, notably Greene G75. There seems to be nothing unusual about the antennae or compound eyes, but the long palpi (presumed to be the maxillary pair) are remarkable. They are exceptionally clear in two specimens (Greene G75 and PE 20790). Such long palpi are very unusual among existing Pterygota. In the orthopteroids, comparable palpi occur in a few species of Gryllacridoidea, especially of the family Stenopalmatidae; so far as known these are wingless and live in rotting wood or are subterranean.

Thorax. The prothorax is the most conspicuous and peculiar part of the thorax. Between the head and the pronotal shield there appears to be a separate, strongly sclerotized segment, which we have interpreted simply as the anterior part of the prothorax. This could conceivably be a sclerotized cervical region, although we are not aware of any such structure in existing insects. It is worthy of note in this connection that a considerable number of Upper Carboniferous Protorthoptera, not especially close to the Eucaenidae, have similar sclerotized regions, although they have not been discussed in the literature.

The pronotal shield shows considerable variation in shape among the specimens studied but a significant part of this diversity is apparently due to the nature of the preservation of the individual specimens. In some instances, the pronotum is obviously different in shape in the counterparts of the same fossil. Handlirsch stated (1911) that the pronotum of the male was comparatively smaller than that of the female, but we have found no reliable evidence for that conclusion.

Wings. The fore wings are distinctly oval in shape; combined with the form of the costal area, this is one of the major characteristics of the insect. The number of costal veinlets is quite variable, as noted above; the costal area of the wings in figures 2 and 3 is based on the Greene specimen G75, which has about the maximum number. The veinlets presumably continue for the full length of the costal area, though the distal part of the area is not satis- 


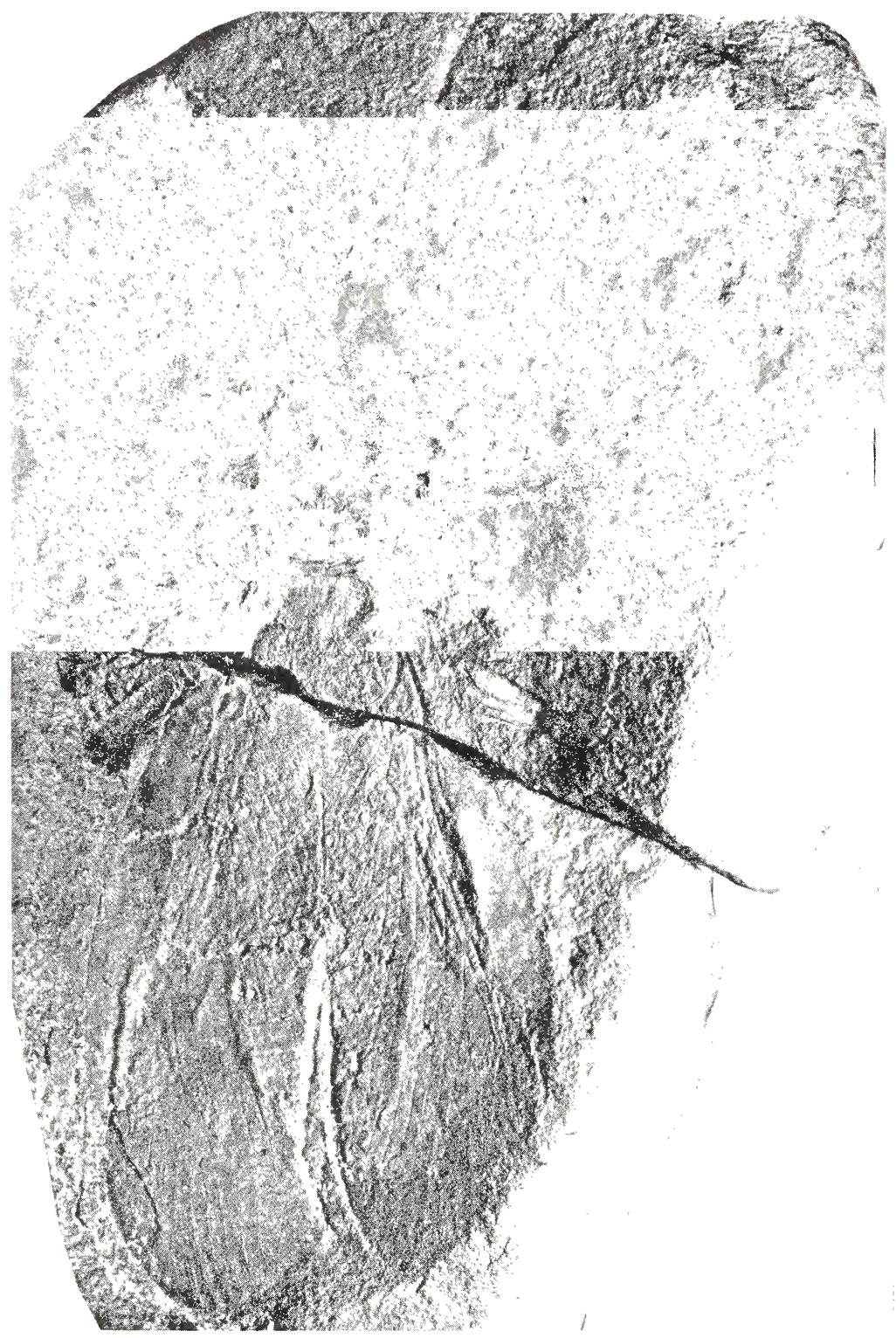

Figure 5. Eucaenus ovalis. Photograph of Field Museum specimen, PE 20790. Length of fore wing, $23 \mathrm{~mm}$. Compare figure 6 . 


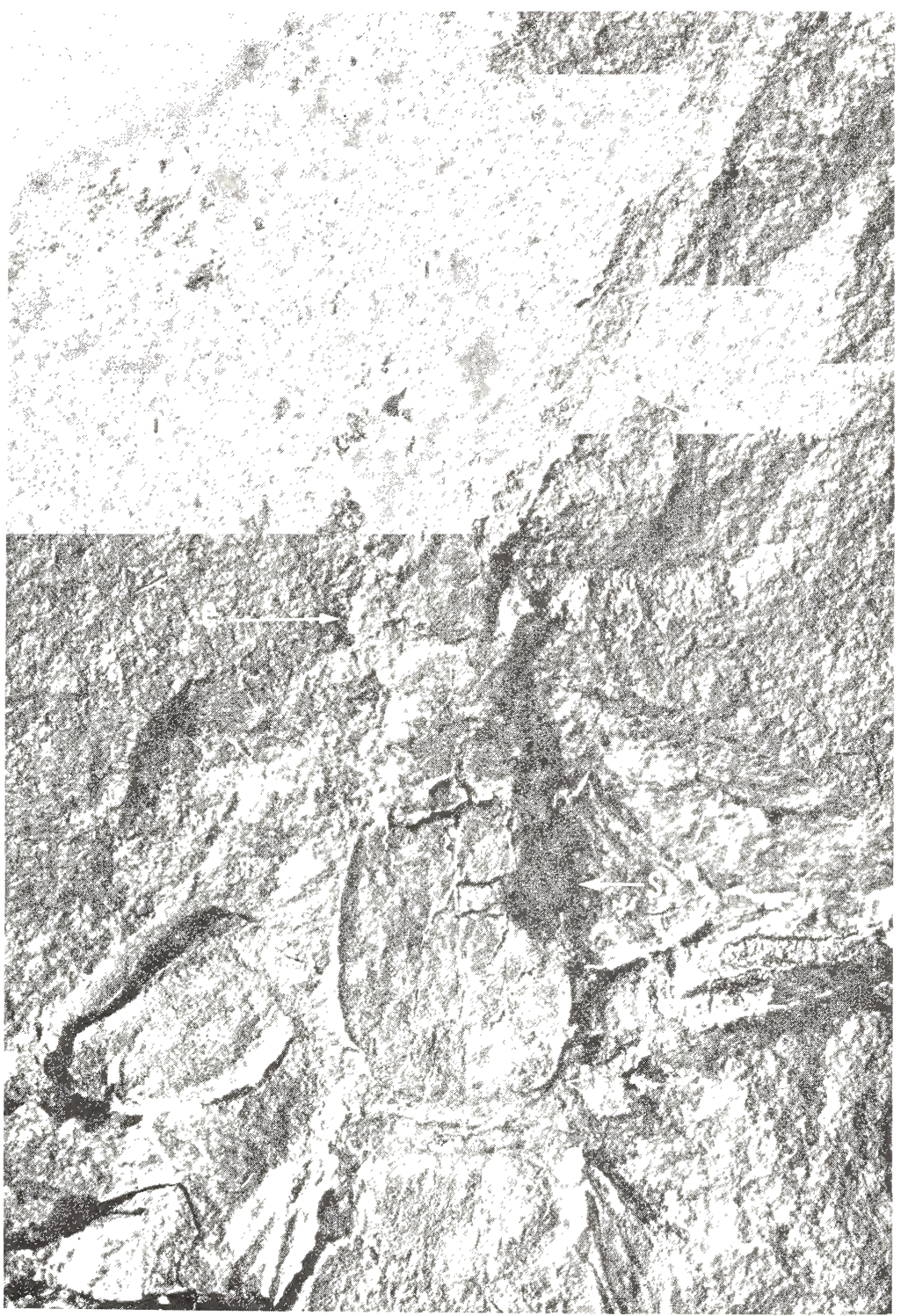

Figure 6. Eucaenus ovalis. Photograph of anterior part of Field Museum specimen, PE 20790, showing details of head and prothorax. Lettering as in figure 4. 
factorily preserved in any specimen; ordinarily that part of the wing is preserved near the edge of the ironstone nodule, where some weathering and discoloration have taken place. Handlirsch's interpretation of the venation of the fore wing of ovalis, as represented in his "reconstruction" $(1911$, p. 360) is obviously incorrect in many respects. RS and $\mathrm{M}$ are much more extensively branched than he represented, and CUA has only a small distal fork, instead of being extensively branched as he has shown. Also, the anal area is somewhat longer than he assumed. Handlirsch's second "reconstruction" (1920, p. 162) is even worse; the branches of $\mathrm{RS}$ are represented as arising dichotomously, not pectinately as he originally (and correctly) showed. However, it should be borne in mind that since none of the specimens that Handlirsch studied showed the fore wing venation clearly enough for an accurate drawing to be made, his figure was mostly conjectural. The cross veins in the wing are very faint at best and it is not surprising that Handlirsch made no reference to them in his descriptions; they are visible, however, in several areas of the wings in two specimens (Sherman W57 and Wolff 653), and in all probability they were quite uniformly distributed over the wing surface in the living insect.

The hind wing of ovalis is unknown except for a few terminal branches of RS near the wing apex. Handlirsch's reconstruction

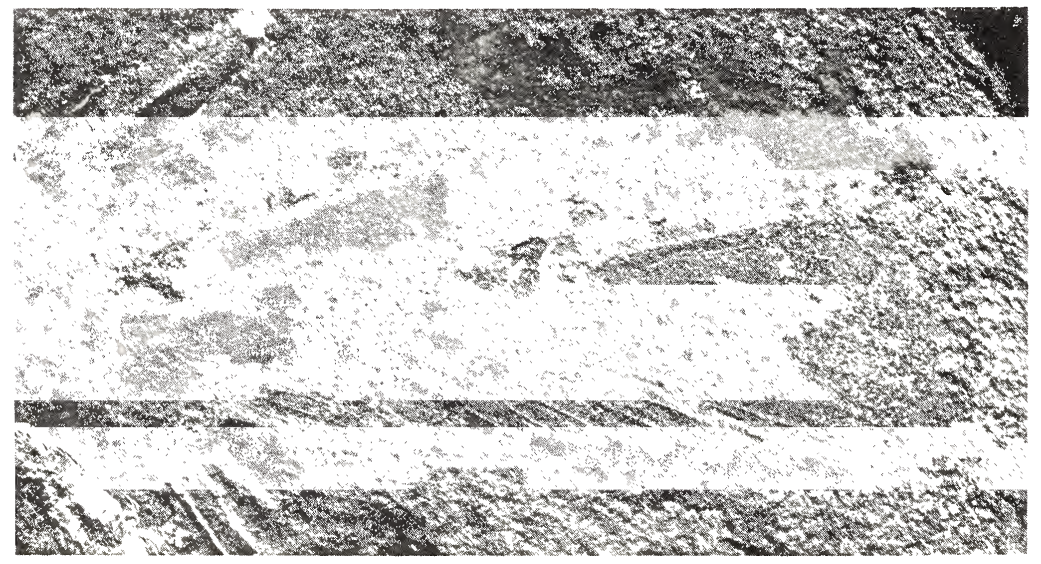

Figure 7. Eucaenus ovalis. Photograph of the Levi Sherman specimen, W57, fore wing only, showing anal area and branching of media and cubitus. length of wing as shown, $15 \mathrm{~mm}$. 
of the hind wing $(1911,1920)$ is either entirely imaginary or based in part on his supposed specimen of mazonus (YPM 51), which, as noted above, is not even a eucaenid.

Abdomen. This is of moderate size and not apparently flattened. The cerci are surprisingly short for a protorthopteron, in most of which they are very prominent structures. The small lobes on the sides of the more posterior segments (and perhaps all segments) resemble comparable structures in other Upper Carboniferous insects; they were noted by Handlirsch (1911, p. 361) in one of the Yale University specimens and are especially clear on most segments of the specimen in the Illinois State Museum (type of T. mirabile). The ovipositor is short, ordinarily not quite reaching the end of the abdomen; this is also unusual for a protorthopteron.

\section{Affinities of the Eucaenidae}

The relationships of the Eucaenidae are difficult to determine, mainly because we know so little about other Protorthoptera with which they might be compared. About $80 \%$ of all described Protorthoptera from the Upper Carboniferous are based on fore wings alone or even on fragments of the wings. Fortunately, the Mazon Creek nodules generally preserve insects with some body parts included, although overlapping of the fore and hind wings usually obscures the abdomen to some extent, as well as the details of the venation. A general survey of the Protorthoptera known from the nodules shows that a substantial number of species are characterized by a prolongation or some other elaboration of the prothorax-certainly a much higher percentage of the known species than occurs in other deposits. However, the nature of the wing venation indicates that at least some of these prothoracic modifications have developed independently within isolated lines of evolution.

There are two families of Protorthoptera from the Francis Creek nodules that appear to show similarities to the Eucaenidae in both prothoracic structure and venation: Cheliphlebiidae and Gerapompidae. Handlirsch consistently placed them close to his Eucaenidae. From both of these families the Eucaenidae differ in having the costal area much broader and in having SC, R1 and the stem of RS close together and parallel. Virtually nothing is 


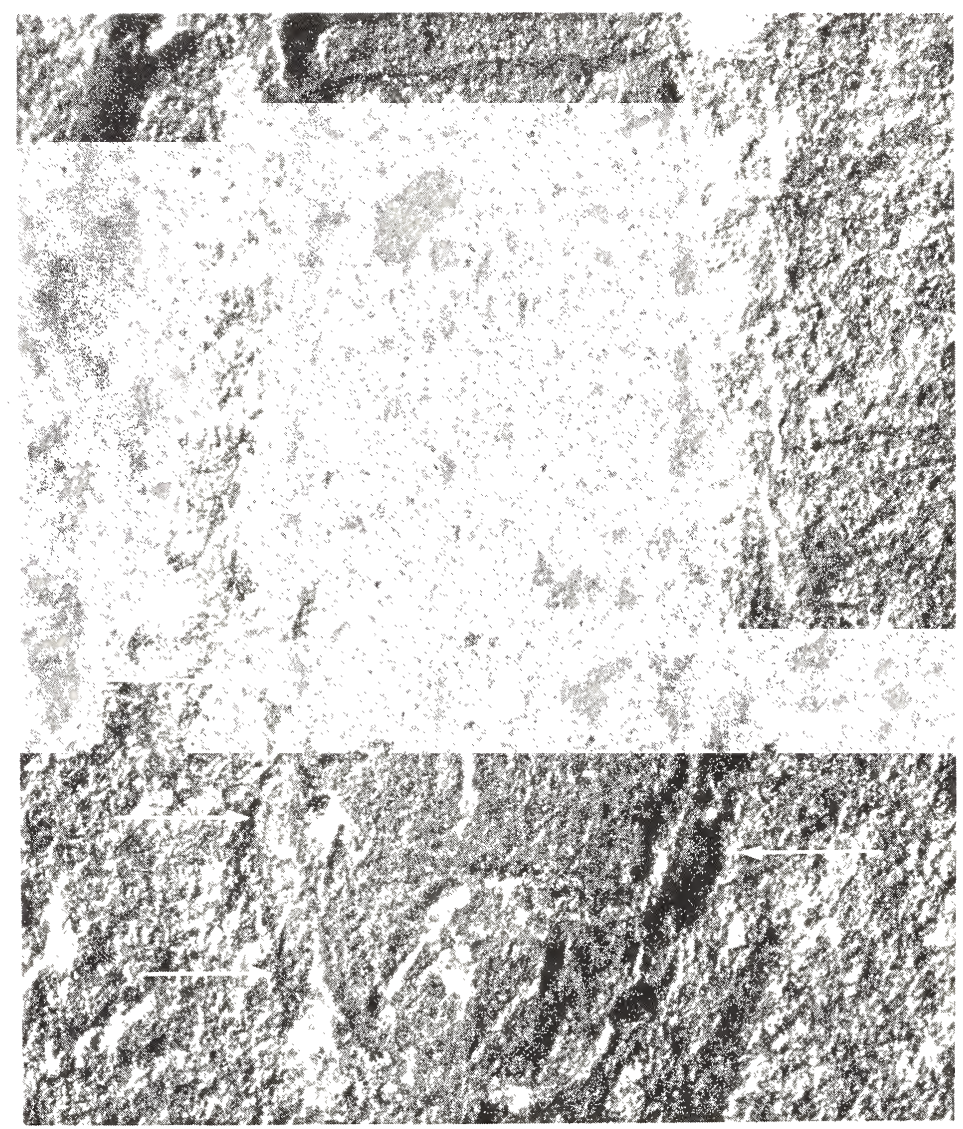

Figure 8. Eucaenus ovalis. Photograph of abdomen of specimen no. 14887 in Illinois State Museum, Springfield (type of T. mirabile). Arrows point to some of the lateral lobes. Length of abdomen as shown, $9 \mathrm{~mm}$.

known about the body structure of these two families except for the enlargement of the prothorax. There are no other Upper Carboniferous families that seem to be close to the Eucaenidae.

Scudder (1885) placed Eucaenus in the neuropteroid section of the Palaeodictyoptera, an order to which he arbitrarily assigned all Paleozoic insects. Handlirsch (1906a, 1906b) recognized its orthopteroid affinities and included it in his new order Protoblattoidea, which he considered an annectant group between the Palaeodictyoptera and the true Blattaria. Since our present knowl- 
edge of the Palaeodictyoptera eliminates them from consideration as ancestral to any existing order, especially the orthopteroid groups, assignment of Eucaenus to the Protorthoptera seems most reasonable. Attempts (e.g., Sharov, 1968) to divide the Protorthoptera into orders or suborders (as the Paraplecoptera, Protoblattodea, and Protorthoptera, leading to the Plecoptera, Blattaria, and Orthoptera, respectively), seem to us to be very premature. The assumption that the orthopteroids of the Upper Carboniferous had already evolved into lines leading to these three orders is most improbable and certainly unjustified on the basis of available evidence; it is much more likely that the Paleozoic orthopteroids, especially those of the Upper Carboniferous, were evolving in many directions. Unfortunately, since most Paleozoic orthopteroids are known to us now chiefly by wings or wing-fragments, we are unable to discern what those directions were. When we know as much about the structure of most other Paleozoic families of the orthopteroids as we do of the Eucaenidae, we will be much better qualified to unravel their evolutionary lines.

Eucaenus ovalis presents a good example of the necessity for a knowledge of body structures in evaluating the affinities of Paleozoic insects. On the basis of its wings, this insect was considered by Scudder, Handlirsch and others to be a primitive roach. We now know that it was a specialized insect, with totally unexpected adaptive modifications and with body structures that remove it from any position leading to the roaches. It provides another illustration (Carpenter, 1971) of the diversity achieved by the insects of the Upper Carboniferous period.

\section{REFERENCES}

Carpenter, F. M.

1943. Carboniferous insects from the vicinity of Mazon Creek, Illinois. I1linois State Museum Sci Papers 3:1-20.

1966. The Lower Permian insects of Kansas, part 11. The Orders Protorthoptera and Orthoptera. Psyche 73:46-88.

1971. Adaptations among Paleozoic insects. Proc N Amer Paleontol Convent Chicago, 1969, part I:1236-1251.

Handlirsch, Anton

1906a. Revision of American Paleozoic insects. Proc US Nat Mus 19:661-820.

1906b. Die Fossilen Insekten. Wien. Pp. 1-1429 [Paleozoic section published in 1906; later parts in 1907 and 1908]. 
1911. New Paleozoic insects from the vicinity of Mazon Creek, Illinois. Amer J Sci (4) 21:297-326; 353-377.

1920. Palaeontologie, in Handbuch der Entomologie (ed. C. Schröder), Bd. III, 7:117-306.

Melander, A. L.

1903. Some additions to the Carboniferous terrestrial arthropod fauna of Illinois. J Geol 11:178-198.

Richardson, Eugene S., Jr.

1956. Pennsylvanian invertebrates of the Mazon Creek area, Illinois. Insects. Fieldiana, Geol 12:15-56.

Richardson, Eugene S., JR. and Ralph Gordon Johnson

1971. The Mazon Creek faunas. Proc N Amer Paleontol Convent Chicago 1969, part I: $1222-1235$.

SCUDDER, S. H.

1885. Palaeodictyoptera: or the affinities and classification of Paleozoic Arthropoda. Mem Bost Soc Natur Hist 3:319-351.

Sharov, A. G.

1968. Phylogeny of the Orthopteroidea. Trudy Paleontol Inst Akad Nauk USSR 118:1-216 [Russian]. Engl. Transl., Israel Progr Sci Transl, 1971, pp. 1-251. 


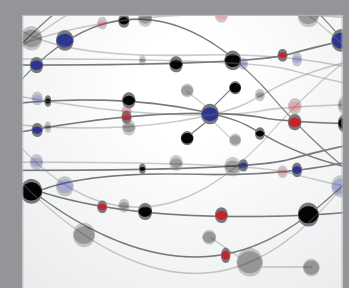

The Scientific World Journal
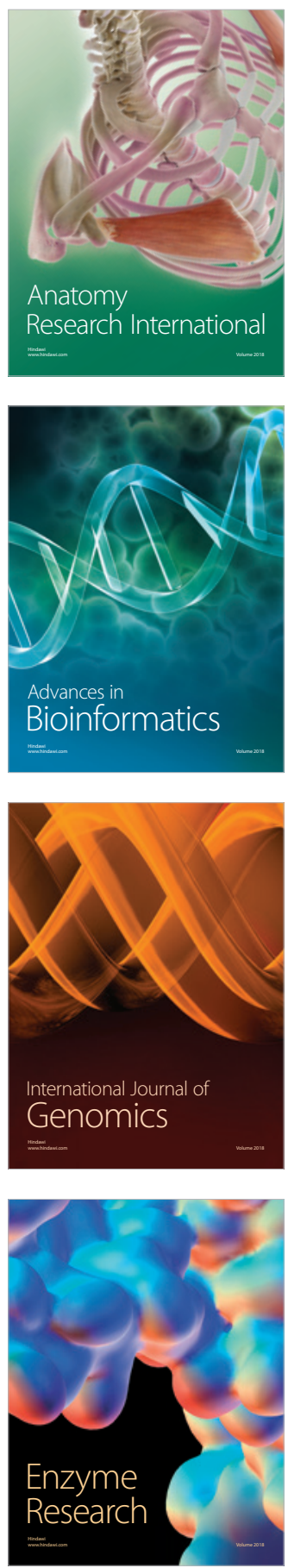
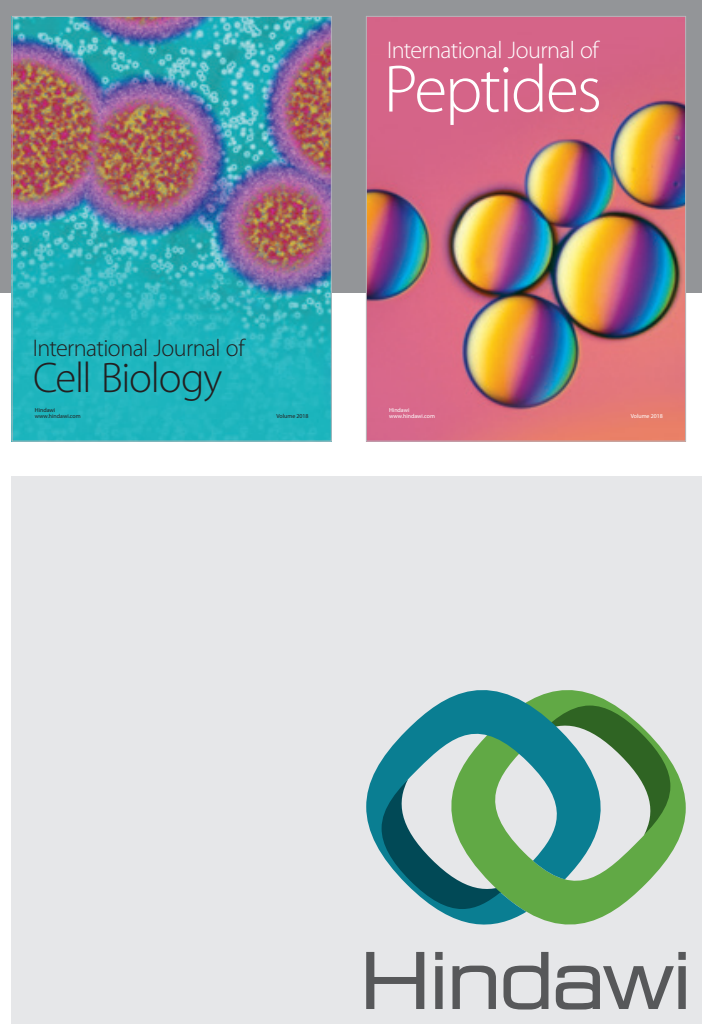

Submit your manuscripts at

www.hindawi.com
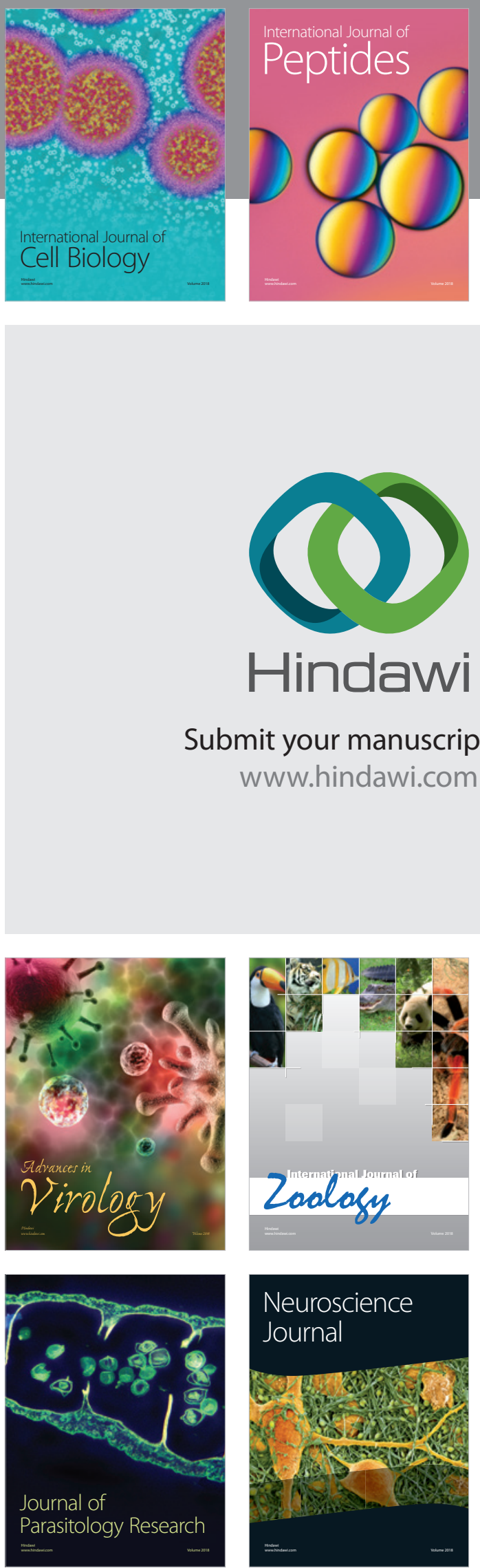
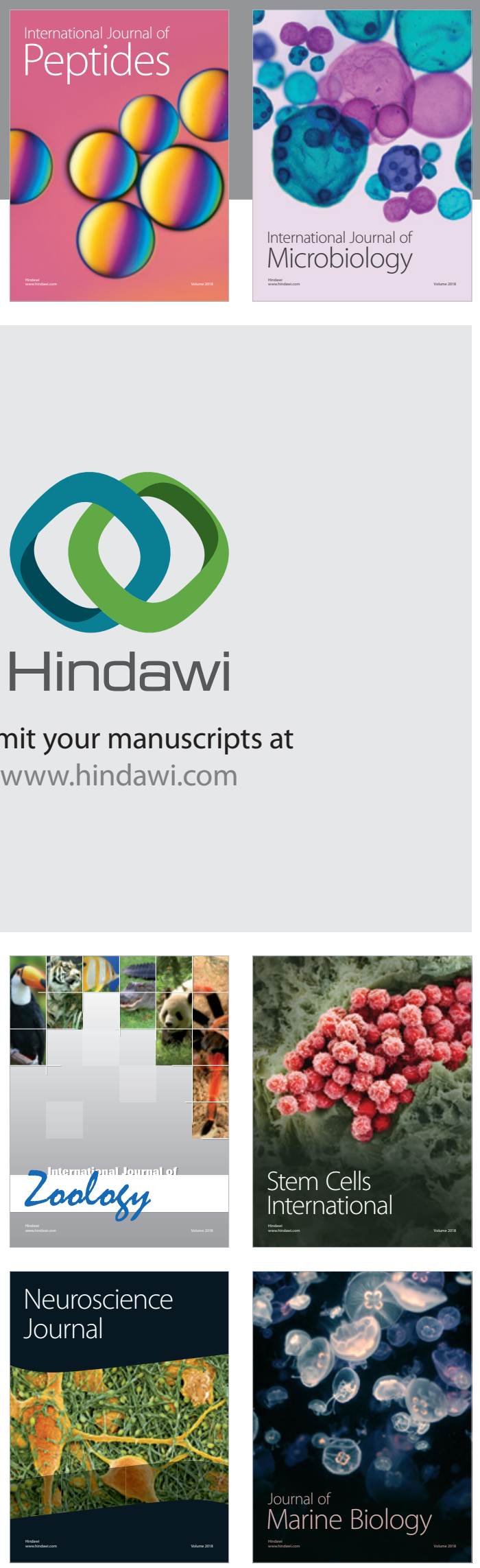
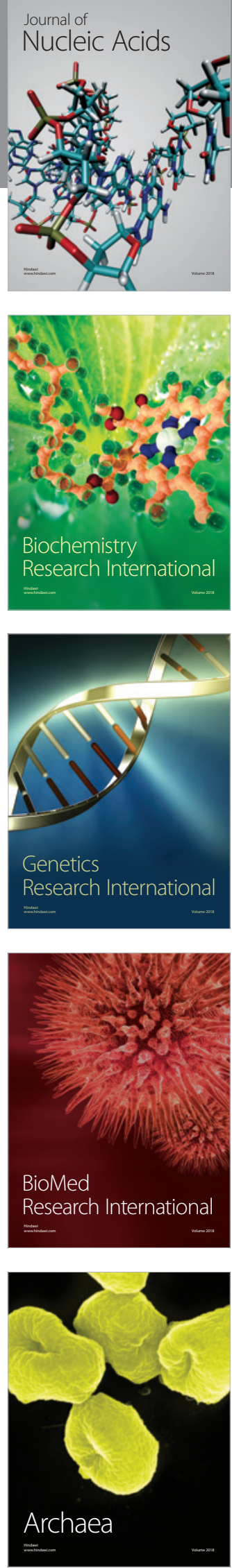